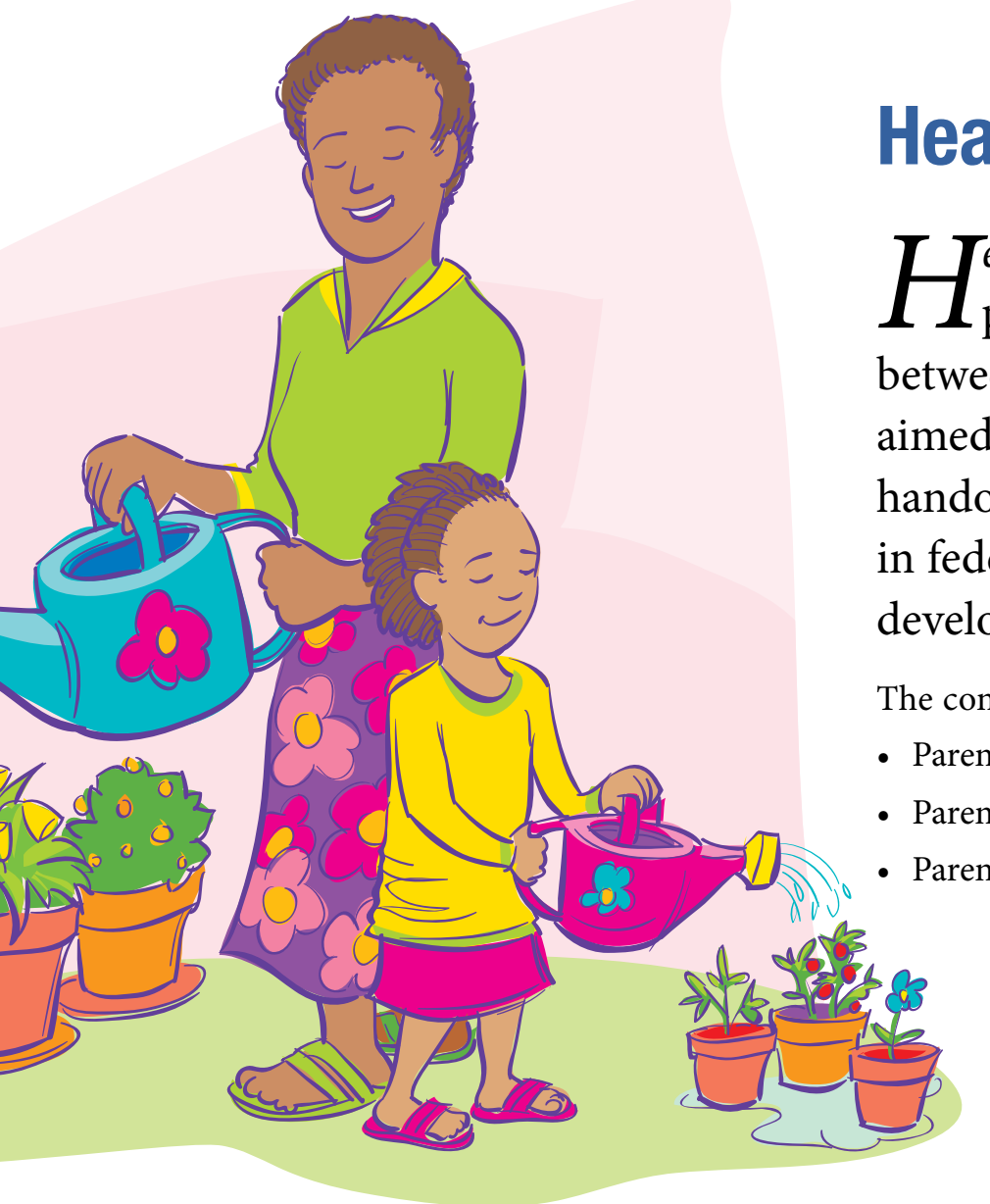

\title{
Healthy, Happy Families Express
}

Tealthy, Happy Families Express is composed of eight handouts designed to help parents learn positive parenting skills that promote healthy eating habits in children between 2 and 12 years of age. The handouts are designed to complement programs aimed at improving children's diet and nutrition in families with limited resources. Each handout focuses on a specific topic identified as relevant through surveys of educators in federally funded nutrition education programs. Each topic area addresses children's development and skills that parents can use to foster healthy dietary behaviors.

The content of the handouts is based on empirical research that shows the following:

- Parents control and shape the environment in which their children develop.

- Parent-child interactions, including those around food, are most effective when done with warmth and sensitivity.

- Parents who have more positive parenting skills are more likely to have positive interactions with their children around food.

- Parents need to begin shaping healthy eating habits early. Children's eating habits begin forming as early as 3 years of age.

- Promoting positive parenting is beneficial to all parent-child interactions, including feeding.

- Positive parenting is associated with better dietary behaviors of children.

LENNA ONTAI, UC Cooperative Extension Family and Early Childhood Specialist, Department of Human and Community Development, University of California, Davis; MARCEL HOROWITZ UC Cooperative Extension Healthy Youth, Families, and Communities Advisor, Yolo County; DRUSILLA ROSALES, Clinical Nutrition Specialist, Texas Children's Hospital; THERESA SPEZZANO

UC Cooperative Extension Advisor in Nutrition, Family, and Consumer Science, Stanislaus County; KARINA DIAZ RIOS, UC Cooperative Extension Specialist in Nutrition, Merced County; CONCEPCION MENDOZA, Retired UC Cooperative Extension Advisor in Nutrition, Family, and Consumer Science, Shasta County; SUE MANGLALLAN, UC Cooperative Extension 4-H Youth and Family Development Advisor, San Diego County; and JONA PRESSMAN, UC Cooperative Extension Nutrition Education Program Manager, Butte County 


\section{Begin Health Habits Early}

"My child isn't hungry at mealtime but wants to eat later. What do I do?"

"How do I get my child to eat the foods I make?"

"I don't like my child to be hungry, so I let him eat whenever he wants."

Your children learn from you. Teach them habits that will last a lifetime. It's okay to set rules for your children. This is how they learn and grow.

Children's bodies send them messages when they are hungry and full. As they grow, they learn lessons about how to respond to these messages. What, when, and where to eat are all lessons they learn from you. Use the following tips to help set your children up for healthy eating.

\section{Parents}

- Decide what food is served.

\section{Children}

- Decide how much to eat from what you serve.

\section{Parents}

- Decide when food is served.

\section{Children}

- Decide whether or not to eat when you serve the food.

\section{Parents}

- Decide where food is served.

\section{Children}

- Decide how much they need to eat to feel full.

\section{Ways to work together}

- Give children healthy choices.

- Help children notice their feelings of hunger and fullness.

- Let children help prepare family meals.

\section{"What if my child is hungry and it's not mealtime?"}

- Serve meals and snacks on a regular schedule each day.

- If it is not meal or snack time, have your child wait until the next one to eat.

- The next meal or snack should happen within the next 2 to 3 hours. If they feel hungry, it won't be too long to wait. Offer water while they wait.

- If they choose to skip dinner, they may go to bed hungry. Plan to serve a hearty breakfast. In time, they will learn not to skip meals.

\section{Things you can do}

$\square$ Tell your child when the next meal or snack will be. "If you don't want what I made for dinner, you won't eat again until breakfast."

$\square$ Serve snacks 1 to 2 hours before the next mealtime. Snacking within 1 hour of a meal can fill children up. You can always offer water.

$\square$ Talk to your child about eating when you feel hungry and stopping when you feel full.

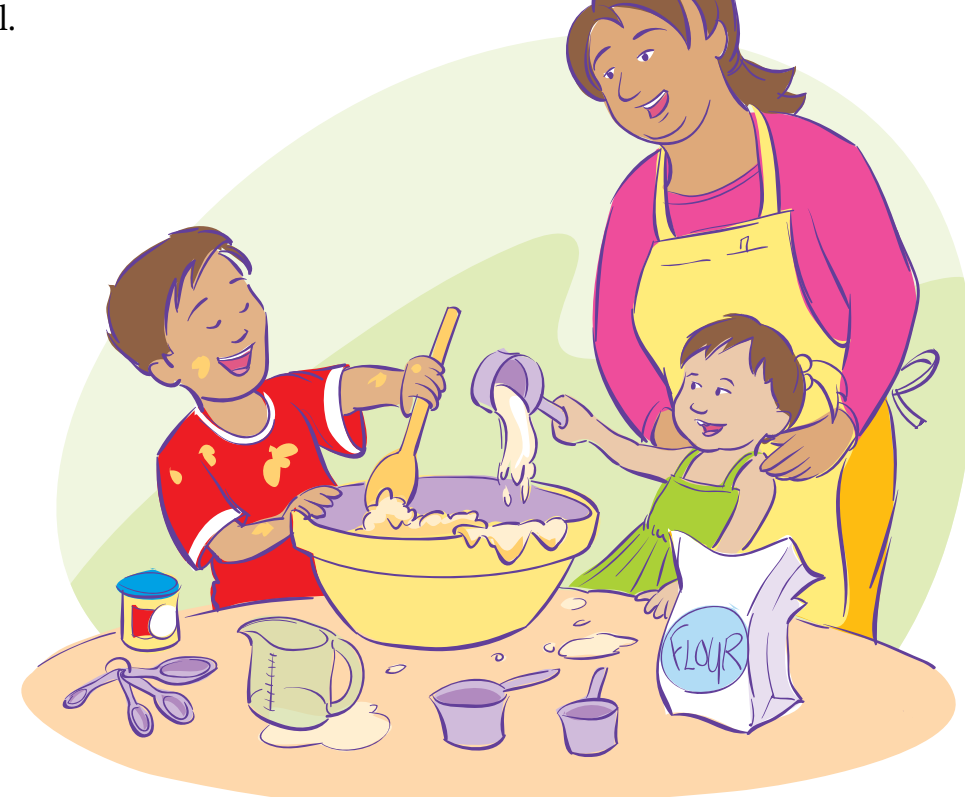




\section{Healthy Routines}

"My child is never hungry at mealtime."

"I don't like my child to be hungry, so I let her/him eat whenever s/he wants to eat."

"My child never wants to eat in the morning!"

Routines are good for children. It lets them know what to expect and makes it easier for them to behave well. Daily routines include sleeping, eating, bathing, and other family habits.

When kids are hungry, they are more likely to eat what they are served. To get your child to eat, make sure your child is coming to meals hungry.

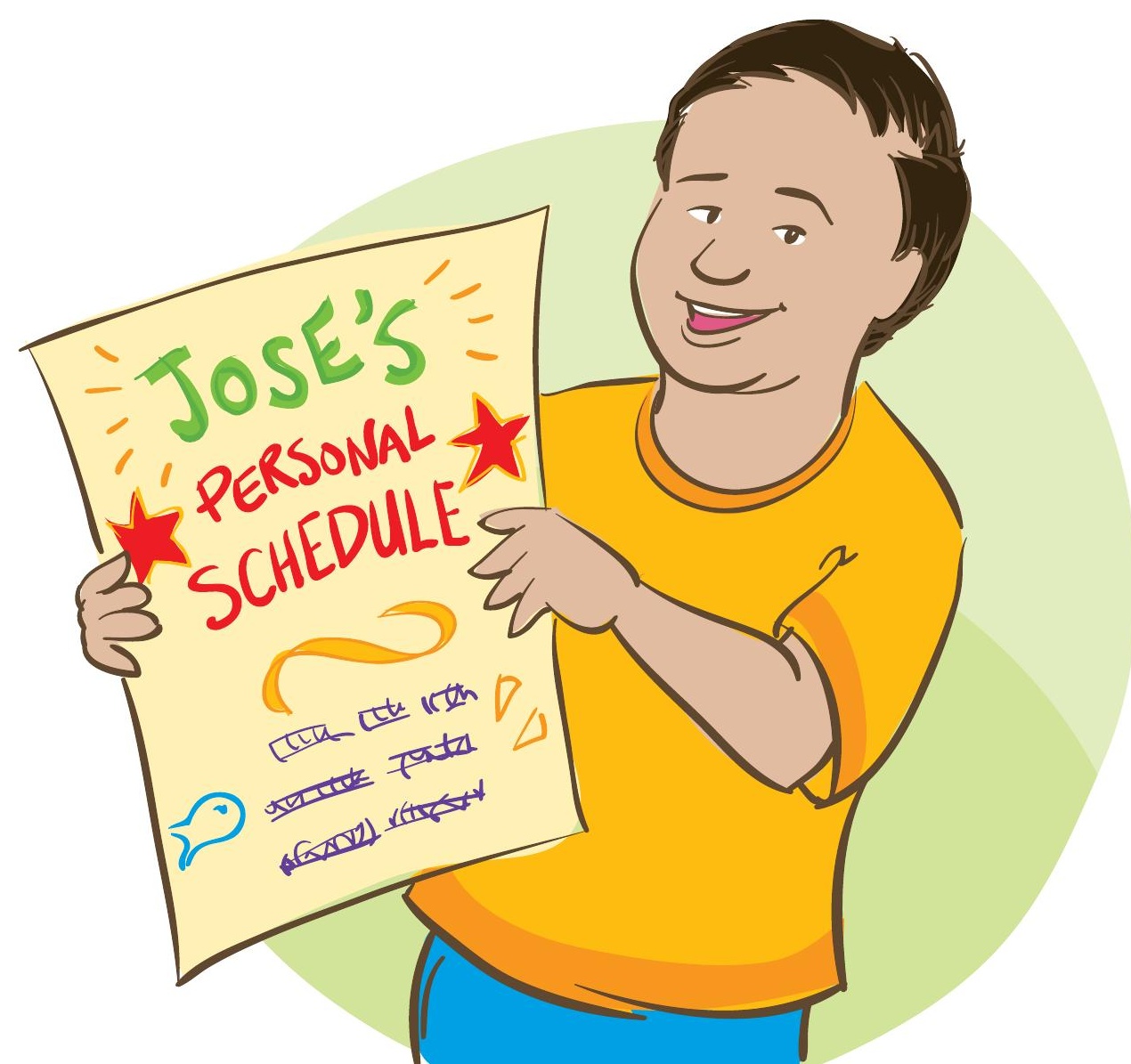

- Space meals and snacks 2 to 3 hours apart. Wait until the next meal or snack time to offer food.

- Offer water in between meals and snacks.

- It's okay if your child feels hungry after skipping a meal. They can eat more at the next mealtime. Soon they will learn not to skip meals.

- Make sure your child wakes up with plenty of time to have breakfast and do other morning activities.

Setting family routines can help the day run smoothly. Successful routines leave enough time to get everything done without being rushed. A morning routine may look something like this:

7:00 Wake up and get dressed / 7:20 Eat breakfast / 7:40 Brush teeth and play / 8:00 Leave

- Routines may seem difficult to start. But children tend to behave better when they are not rushed and when they know what to expect.

- Routines need to change as children get older and have different responsibilities. Think about how much time your child needs to do each task and make adjustments. For example, they may need to go to bed earlier at night if they need more time to get ready in the morning.

\section{Things you can do}

$\square$ Tell them the plan. Remind your child of the schedule and what you will be doing next.

$\square$ Set regular bedtimes, wake up times, and mealtimes.

$\square$ Plan your day with your child in mind. Run errands when your children are not hungry or tired.

$\square$ If your routine gets off track, just try again the next day. 


\section{Watching Children Grow}

"Do I need to do the same things with my younger child as with my older one?"

"My older child cares more about what his friends are doing than what I want him to do."

Needs change as children get older. Younger children need more help from parents. As they get older, it is good for them to have chances to make decisions on their own. However, even older kids need parents to guide them. Parents can help children learn how to make smart and healthy decisions.

- Set clear expectations for young children that fit their abilities. Be sure to have the same expectations for behavior in different settings.

- Older children can follow rules on their own. When this happens, you can start giving them chances to make their own decisions.

- Start by having older children make their own breakfast. Begin by giving guidelines about what to include (a grain, a fruit, a protein). Let them choose what foods to pick.

- Try giving guidelines for other choices until children learn to make smart healthy decisions on their own.

- Children who know how to make good choices on their own do better with peer pressure.

Sleep needs also change. When kids get enough sleep, they eat well and do better in school. Young children need more sleep than older children. But even older children need more sleep than adults.

\begin{tabular}{|l|l|}
\hline Child's age & Sleep needed each day \\
\hline $\begin{array}{l}\text { Newborns ( } 0 \text { to } 3 \text { months) } \\
\begin{array}{l}\text { Infants and toddlers (4 months to } 2 \\
\text { years) }\end{array}\end{array}$ & 14 to 17 hours (including naps) \\
\hline Preschool-aged (3 to 5 years) & 10 to 13 hours (including naps) \\
\hline School-aged (6 to 13 years) & 9 to 11 \\
\hline Teenagers (14 to 17 years) & 8 to 10 hours \\
\hline
\end{tabular}

Source: Hirshkowitz et al. 2015.
This means that a 5-year old who needs to wake up at 7 a.m. should be asleep by 9 p.m. to get 10 hours of sleep. And a 10-year old who needs to wake up at 7 a.m. would need to be asleep by 10 p.m.

\section{Things you can do}

$\square$ Use the same bedtime and wake-up time every day. Even on weekends.

$\square$ Put your children to bed 20 to 30 minutes before they should be asleep.

$\square$ Set a bedtime routine with quiet activities like reading books together.

$\square$ Make the bedroom quiet and dark. Leave TVs and other electronics out of the bedroom.

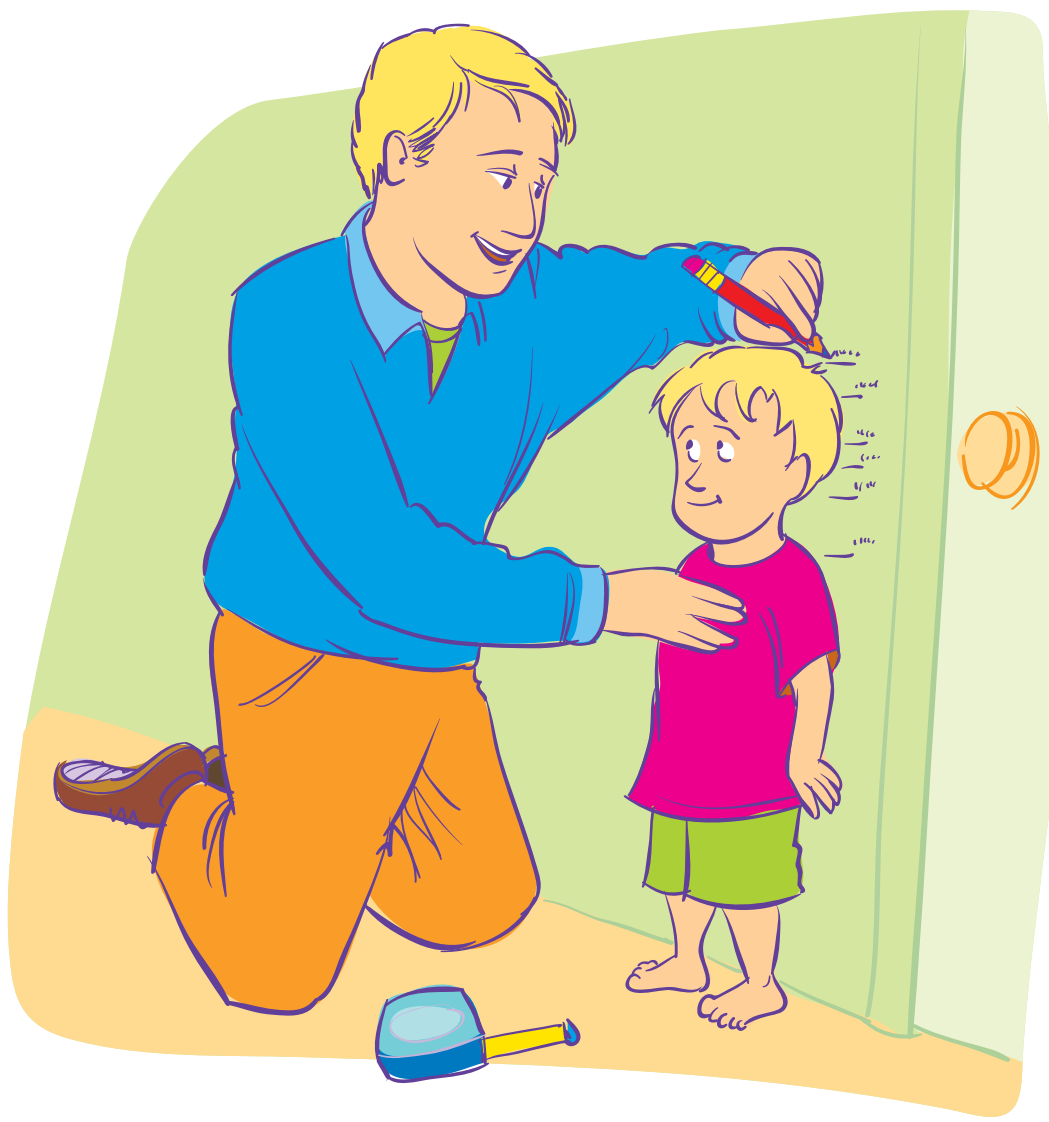




\section{Rewarding Positive Behavior}

"My children have a meltdown if I tell them they can't have candy." "How do I get my child to behave well if I don't use food?"

Kids act out. It is one way they learn the rules. Teaching them how to control their behavior is part of your job as a parent. Sometimes parents give treats for good behavior or for eating vegetables. Try to praise good behavior with words instead of food.

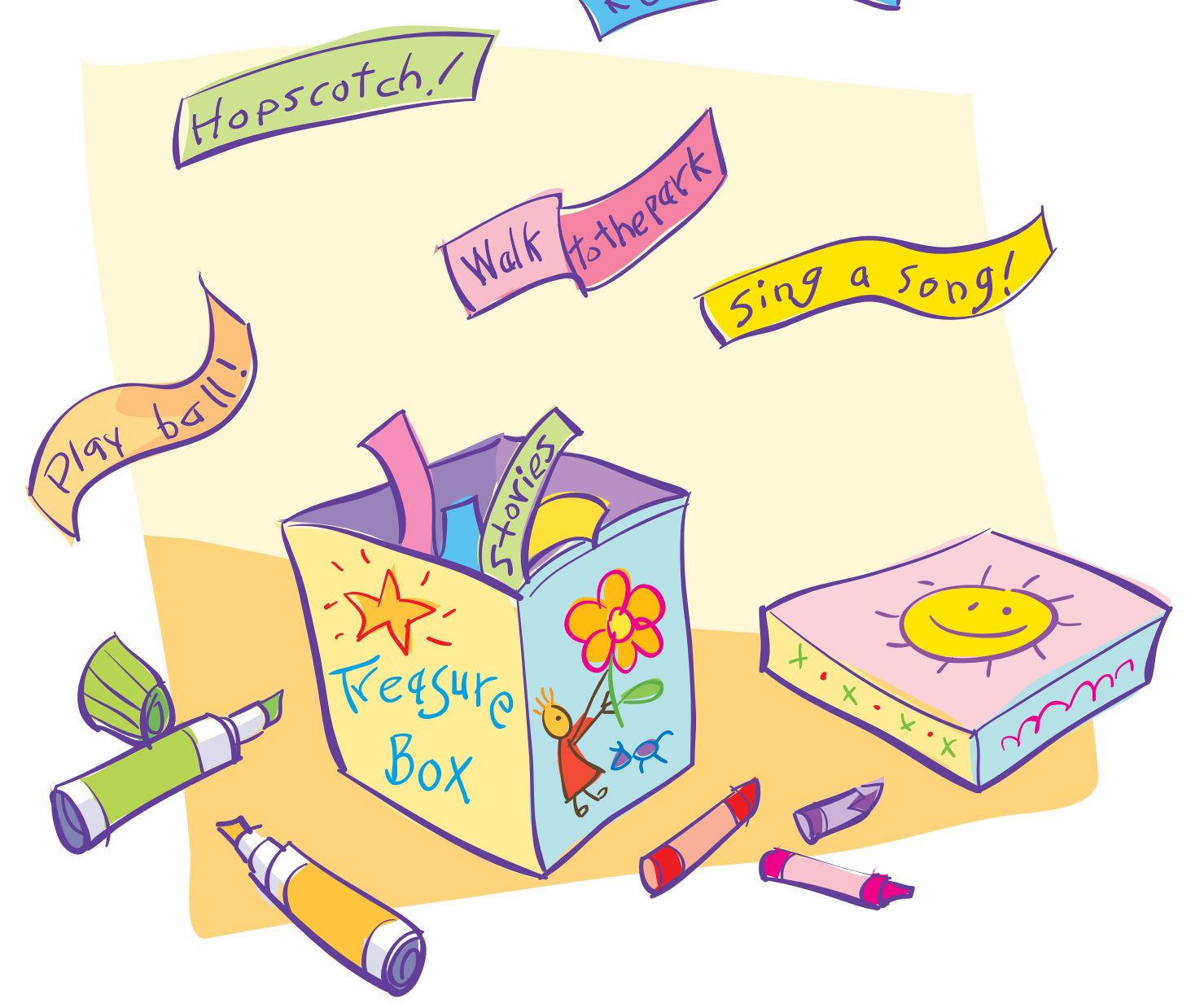

\section{Why not reward with food?}

- Children should learn to eat only when they are hungry.

- Giving rewards for eating everything on their plates can teach children to overeat.

- Comforting children with food teaches them to use food to feel good inside.

- Children learn to like treats better than healthy foods.

\section{How to encourage good behavior}

- Clearly explain your rules and why you have them. They learn what to expect.

- Keep your rules short and easy to follow.

- Notice and praise good behavior. Children learn faster with praise than punishment.

- Keep your voice positive and firm. Yelling can make them tune out.

- Use the same rules every time. This makes it easier for them to learn.

\section{Things you can do}

$\square$ Point out good behavior with praise. “Good job!" "I'm proud of you!" "High five!"

$\square$ Use time together as rewards for good behavior. Try playing games, cards, singing, or doing crafts.

$\square$ Use low-cost toys for rewards: stickers, crayons, jump rope, puzzles.

$\square$ Be consistent. Try to notice the same behavior each time it happens. 


\section{TEAM FAMILY}

"What do I do about other adults in the family (e.g., grandparent, partner) who feed unhealthy foods to my child?"

"How can I get my partner to stop offering our kids soda?"

Kids learn from watching what the adults in their family do, not just what they say. They want things to be "fair." When they see a parent or grandparent doing something, they want to do it too. It is important for everyone in the house to follow the same rules.

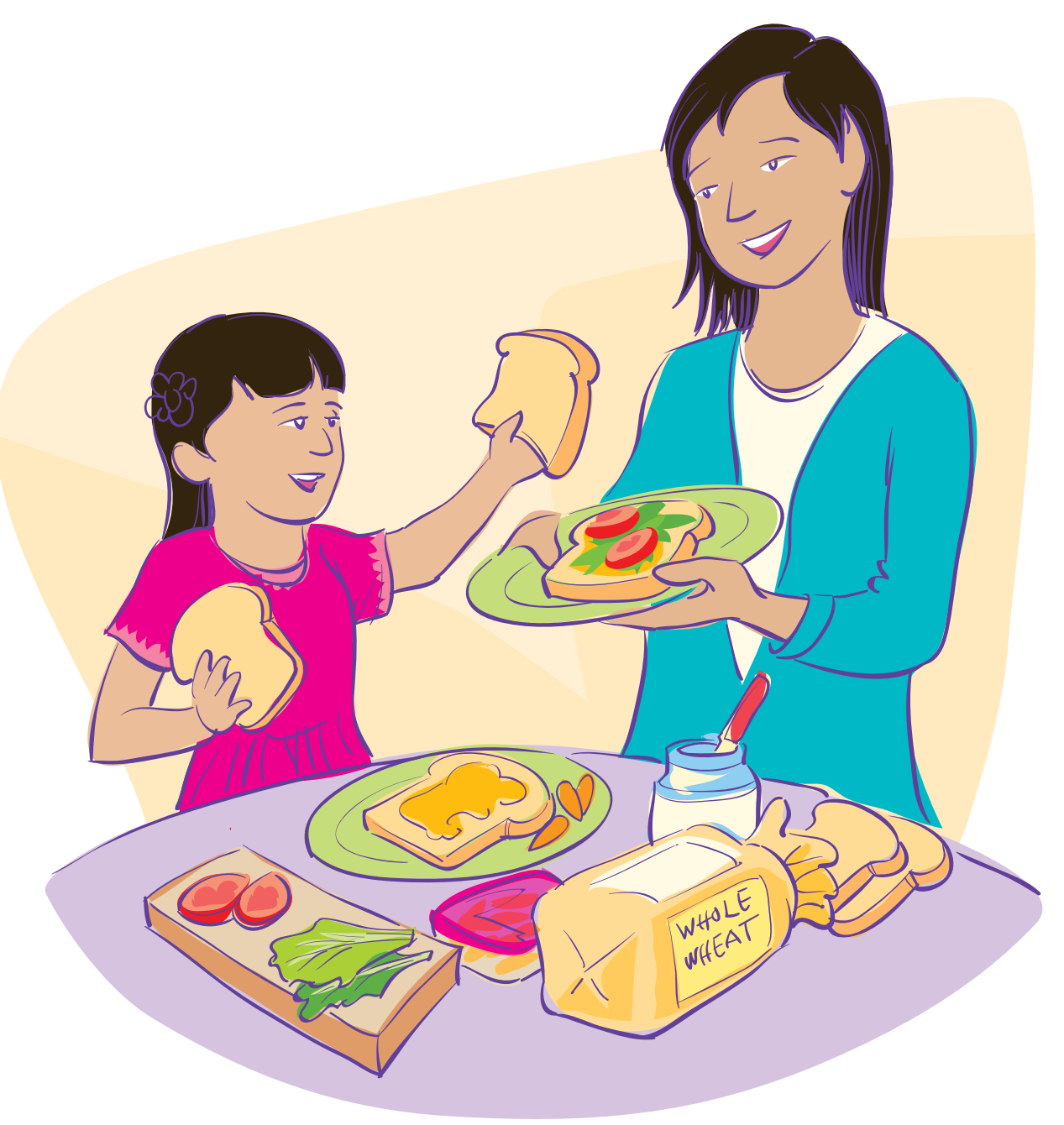

\section{Make your family a team:}

- Food decisions are part of parenting. Get on the same page with each other, just like with other parenting decisions.

- Compromise. Allow certain foods at special events or certain days.

- Decide on your shared values for your kids. Healthy eating helps children's health, grades, and good behavior.

- Set family rules and post them in a shared space. "Water or milk with meals." "TV off during dinner." Make sure everyone follows them-including adults.

- Make all foods available to everyone. Avoid separate "adult foods."

- Keep only healthy foods available in your house.

Other caregivers:

- Meet with other caregivers to share your family rules. Remind caregivers to keep the same rules when they watch your child.

- Check in after they care for your child. Ask what your child ate, how he/she slept and behaved.

- Work together to create solutions for your child. For example, if you want your child to eat more vegetables, ask other caregivers to try serving vegetables to your child, too.

\section{Things you can do}

$\square$ Don't give up. Special events, grandparents, and friends may not follow the same rules you have in your home. Make sure that children know what the rules are at home.

$\square$ Be a role model. Remember that children want to eat what they see you eat.

$\square$ Be consistent. Remind the adults in your child's life to follow the rules you set.

$\square$ Share these materials with them. Let them learn with you. 


\section{EATING TOGETHER}

"How do I get everyone to eat the same meal?"

"I have to cook different meals for everyone."

\section{Why should kids and adults eat the same meal?}

- Children learn from watching adults. You pass along family values with your behavior.

- Children will learn to like the family foods.

- It saves time and money.

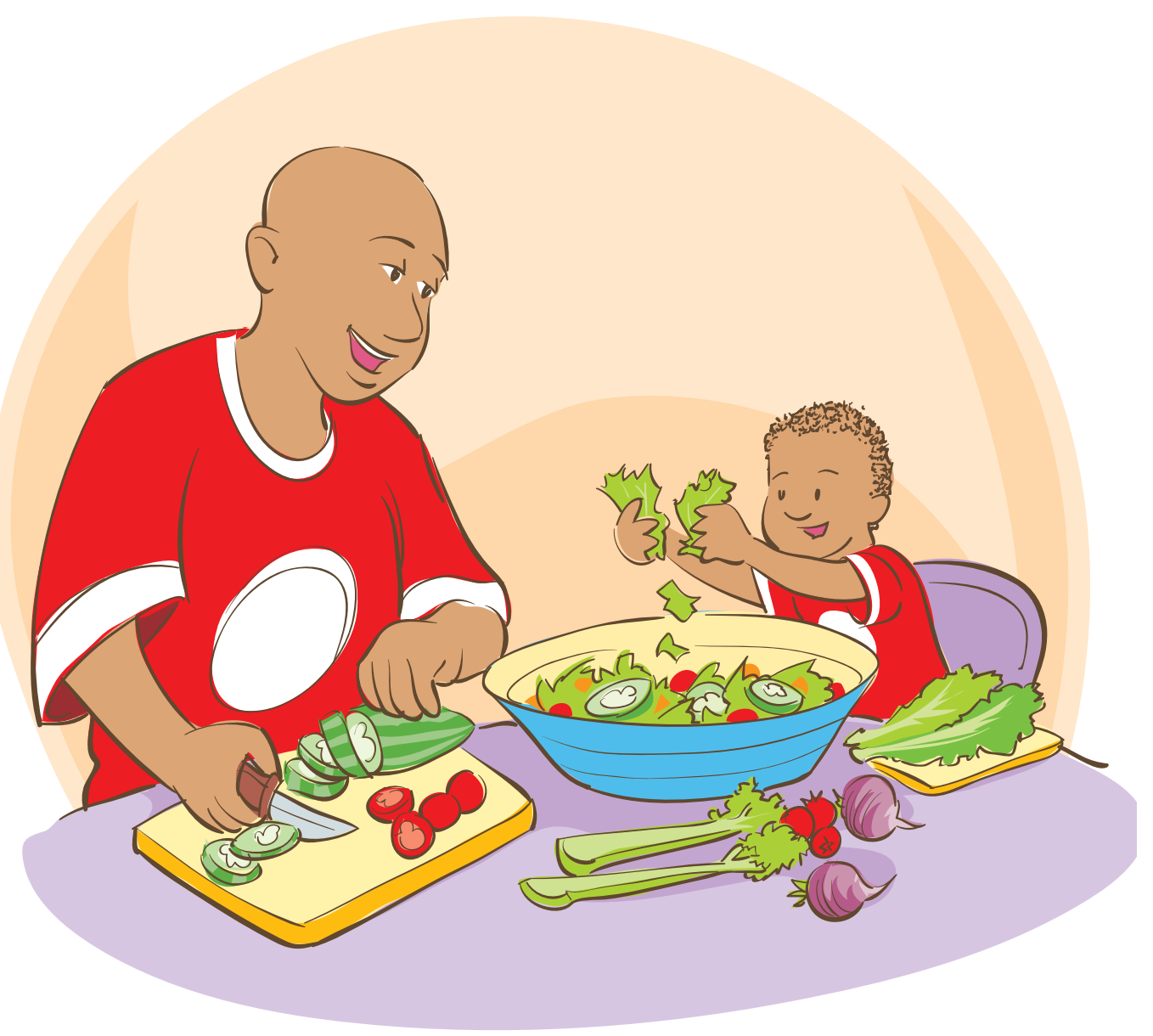

\section{How to serve one meal for everyone}

- Use "MyPlate" as a guide for meal planning. Serve something in each food group.

- Serve meals "family style." Put food on the table and let everyone serve themselves. It's okay if they don't eat some of each food offered.

- Make sure there are at least 1 to 2 items that each family member likes. Everyone can pick which foods they want to eat.

- The food served is the only option. Don't allow people to prepare their own meal when they don't like what is served.

- Including a vegetable is easy. Try adding a bowl of baby carrots or frozen peas.

\section{Ways to involve your kids}

- Let each child plan one meal each week.

- Younger kids can tear lettuce for salads, slice soft fruits and veggies, or set the table.

- Older kids can help measure, stir, and even cook with your help.

\section{Things you can do}

$\square$ Make food prep easy. Have staples in the house to create quick meals everyone likes: whole grain bread, pasta, rice and tortillas, beans, cheese, tomatoes, lettuce, onions, milk, cereal, etc.

$\square$ Include everyone in the weekly meal planning. Ask for suggestions. Or give everyone a day of the week to choose the menu.

$\square$ Eat with your children. Let them see you enjoying healthy foods. 


\section{EnJoying Family Meals}

"It's too hard for our family to eat together."

"We're too busy to have a family meal."

"My kids won't sit still long enough for a family meal."

It pays off to have family meals. Kids who eat with their parents do better in school. And they learn to make healthy food choices. Family meals also give busy families time to spend together and create lasting memories.

\section{How to create a family meal}

- Make meal prep easy. Mix homemade and prepared food, like salads in bags, canned fruit, pasta/veggie combinations.

- Make it at a regular time. Choose a time of day when most people can be together.

- It does not have to be every day. Choose days when schedules are not as busy.

- Plan meals ahead. It saves time, money, and makes it easy.

- Serve one or two foods that each person likes so everyone will eat.

\section{Make family mealtime fun}

- Talk and enjoy each other.

- Keep it positive. Share the favorite part of your day or ask what people are looking forward to doing tomorrow.

- Keep it short. Young kids will only sit still for 10 to 15 minutes.

- Bring kids to the table hungry and ready to eat. Keep the hour before mealtime free of snacks.
- Keep it calm. Turn off the TV and phones. It makes it easier to focus on each other.

- Have children mark family meal days on a calendar with a special sticker.

\section{Things you can do}

$\square$ Start with small changes. Anytime you eat together can be a family meal.

$\square$ Choose a quiet place. Turn off TVs and phones.

$\square$ Find a comfortable place. Use any type of table or try a blanket on the floor.

$\square$ Ask children to help. Let them set the table and help with food preparation or cleanup.

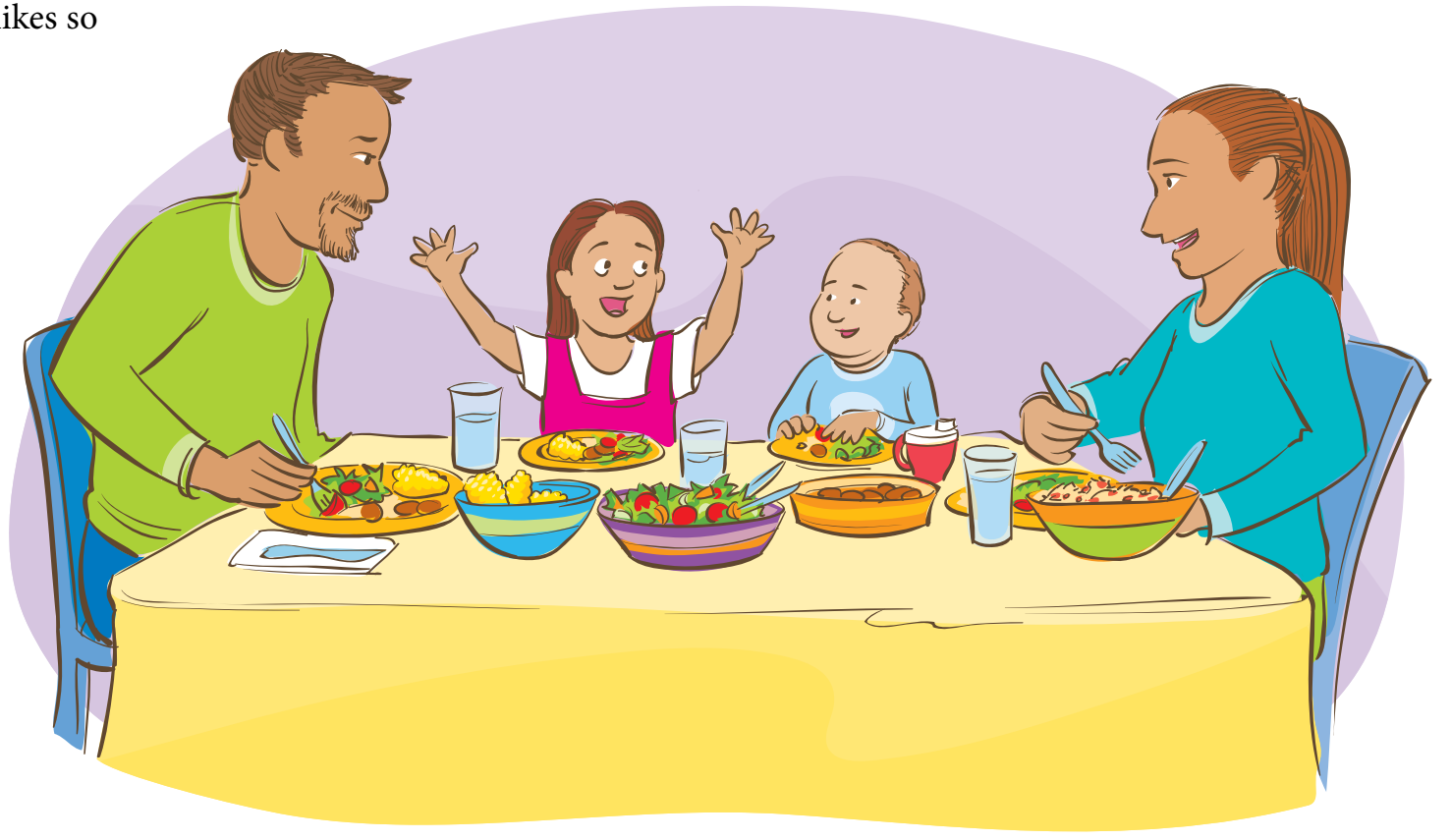




\section{Trying New Foods}

"My children are picky eaters! How do I get them to try more foods?" "My kid won't eat vegetables."

"My child will eat only certain fruits and vegetables."

"How do I get my child to eat more vegetables?"

Some children are picky eaters. They may not like the flavor, texture, or feel of certain foods. Keep trying. Children of any age can learn to like new foods.

- Be a role model. Let your children see you eating fruits and veggies.

- Serve new foods with familiar ones.

- Try to give fruit and vegetable choices at each meal. For instance, if you normally serve a salad, add a bowl of carrot sticks and a can of fruit.

- Help your child learn what foods they like and don't like. Hiding vegetables in other foods doesn't let them learn which ones they like.

- Try serving them different ways: steaming, grilling, freezing, or raw.

- Talk about the food. Describe the color, texture, smell, and taste.

\section{For younger children}

- They may need to see a food at least 10 times before trying it.

- Let them explore new foods. Licking, squishing, and spitting out is okay.

- Make it fun! Offer different colors or serve with dips.

\section{For older children}

- Let your child select the fruits or vegetables to serve at dinner. Have them help prepare them.

- Offer two choices: "Would you like broccoli or cauliflower with dinner?" "Would you like a peach or watermelon with lunch?"

\section{Things you can do}

$\square$ Plan ahead. Introduce new foods when children are most hungry.

$\square$ Get children involved. Let them choose healthy new foods at the store.

$\square$ Cook together. Let children taste as you go.

$\square$ You don't have to waste food. Buy small portions or frozen fruits and vegetables until you know your child will eat it.

$\square$ Be a good example. Children want to eat what they see you eat.

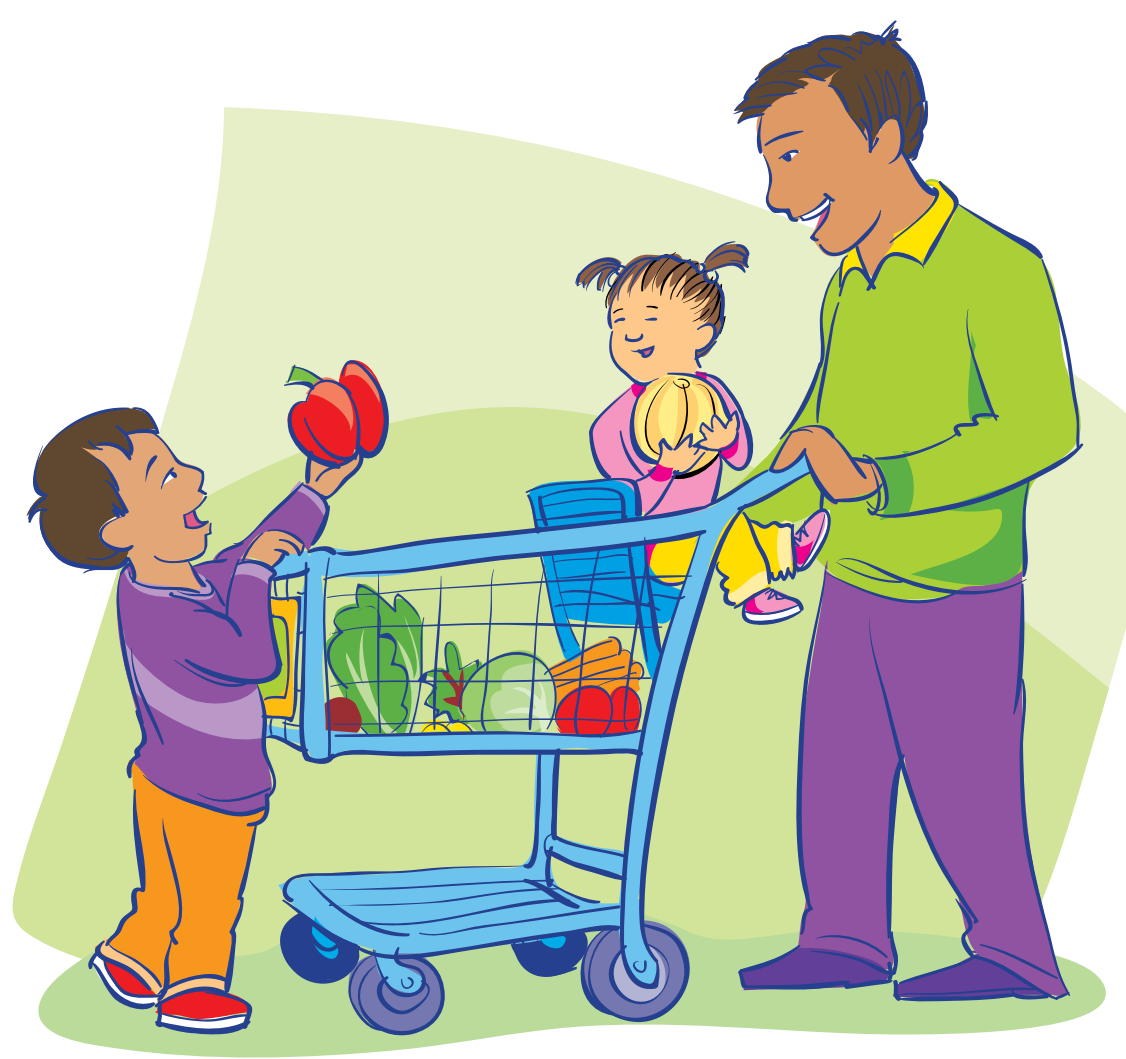




\section{REFERENCES}

Hirshkowitz, M, K. Whiton, S. M. Albert, C. Alessi, O. Bruni, L. DonCarlos, N. Hazen, and J. Herman. 2015. Sleep health. Journal of the National Sleep Foundation 1(4): 233-243.

\section{For Further Information}

To order or obtain ANR publications and other products, visit the ANR Communication Services online catalog at http://anrcatalog.ucanr.edu/ or phone 1-800-994-8849. You can also place orders by mail or FAX, or request a printed catalog of our products from

University of California

Agriculture and Natural Resources

Communication Services

2801 Second Street

Davis, CA 95618

Telephone 1-800-994-8849

E-mail: anrcatalog@ucanr.edu

(c)2018 The Regents of the University of California. This work is licensed under the Creative Commons Attribution-NonCommercial-NoDerivatives 4.0 International License. To view a copy of this license, visit http://creativecommons.org/licenses/by-nc-nd/4.0/ or send a letter to Creative Commons, PO Box 1866, Mountain View, CA 94042, USA.

Publication 8587

ISBN-13: 978-1-62711-000-6

Illustrations by Will Suckow.

The University of California, Division of Agriculture and Natural Resources (UC ANR) prohibits discrimination against or harassment of any person in any of its programs or activities on the basis of race, color, national origin, religion, sex, gender, gender expression, gender identity, pregnancy (which includes pregnancy, childbirth, and medical conditions related to pregnancy or childbirth), physical or mental disability, medical condition (cancerrelated or genetic characteristics), genetic information (including family medical history), ancestry, marital status, age, sexual orientation, citizenship, status as a protected veteran or service in the uniformed services (as defined by the Uniformed Services Employment and Reemployment Rights Act of 1994 [USERRA]), as well as state military and naval service.

UC ANR policy prohibits retaliation against any employee or person in any of its programs or activities for bringing a complaint of discrimination or harassment. UC ANR policy also prohibits retaliation against a person who assists someone with a complaint of discrimination or harassment, or participates in any manner in an investigation or resolution of a complaint of discrimination or harassment. Retaliation includes threats, intimidation, reprisals, and/or adverse actions related to any of its programs or activities.
UC ANR is an Equal Opportunity/Affirmative Action Employer. All qualified applicants will receive consideration for employment and/or participation in any of its programs or activities without regard to race, color, religion, sex, national origin, disability, age or protected veteran status.

University policy is intended to be consistent with the provisions of applicable State and Federal laws.

Inquiries regarding the University's equal employment opportunity policies may be directed to: Affirmative Action Contact and Title IX Officer, University of California, Agriculture and Natural Resources, 2801 Second Street, Davis, CA 95618, (530) 750-1397. Email: titleixdiscrimination@ucanr.edu. Website: http://ucanr.edu/sites/anrstaff/Diversity/ Affirmative_Action/.

An electronic copy of this publication can be found at the ANR Communication Services catalog website, http://anrcatalog.ucanr.edu/.

UC This publication has been anonymously peer reviewed for technical accuracy by REVIEWED University of California scientists and other qualified professionals. This review process was managed by ANR Associate Editor for Human and Community-Youth Development Katherine Soule.

web-12/18-LR/WS 